Research Journal of Animal Sciences 11 (5-6): 12-17, 2017

ISSN: $1993-5269$

(C) Medwell Journals, 2017

\title{
Analysis of Genetic Variation in RYR 1 and H-FABP in PSS Pigs using SNP Genotyping
}

\author{
${ }^{1,2}$ Jhy-Ming Li, ${ }^{1}$ Yen-Ming Horng, ${ }^{2}$ Yi-Ting Chen, ${ }^{3} \mathrm{Mu}-\mathrm{Chiou}$ Huang and ${ }^{1} \mathrm{Chean}$-Ping Wu \\ ${ }^{1}$ Department of Animal Science, National Chiayi University, 300 Syuefu Road, Chiayi, Taiwan \\ ${ }^{2}$ Division of Colon and Rectal Surgery, Department of Surgery, Chang Gung Memorial Hospital, \\ No. 6, Sector W., Jiapu Road., Puzi City, 613 County Chiayi, Taiwan \\ ${ }^{3}$ Department of Animal Science, National Chung Hsing University, 250 Kuo-Kuang Road,
} Taichung, Taiwan

\begin{abstract}
The present study investigated the genetic variations in the Ryanodine Receptor 1 (RYR1) and Heart Fatty Acid-Binding Protein (H-FABP) genes, responsible for Porcine Stress Syndrome (PSS) observed during auction in pigs. A total of 655 pigs were sampled during either transportation or auction period. A SNaPshot assay, combining multiplex PCR with multiplex primer extension assay was used for targeted detection of all mutations in one reaction. The most frequent RYR1 genotype was the recessive $\mathrm{nn}$, followed by the heterozygous $\mathrm{Nn}$ and the dominant $\mathrm{NN}$. Investigation of the $\mathrm{H}$ locus of the $5^{\prime}$ upstream region in H-FABP showed that the genotype frequencies of $\mathrm{HH}, \mathrm{Hh}$ and hh were $0.82,0.16$ and 0.03 , respectively. Furthermore, analysis of the $\mathrm{D}$ and $\mathrm{A}$ loci in the intron 2 region of $\mathrm{H}-\mathrm{FABP}$ showed that the genotype frequencies of $\mathrm{DD}, \mathrm{Dd}$ and dd were $0.03,0.39$ and 0.59 and those of $\mathrm{AA}, \mathrm{Aa}$ and aa were $0.47,0.51$ and 0.02 , respectively. Thus, a high incidence of PSS was associated with $\mathrm{HH}, \mathrm{dd}, \mathrm{Dd}, \mathrm{Aa}$ and AA and a low rate with $\mathrm{Hh}, \mathrm{hh}, \mathrm{DD}$ and aa. In conclusion, a positive correlation was found between the PSS development and SNP genotypes of RYR1 but not H-FABP.
\end{abstract}

Key words: Auction market, heart fatty acid-binding protein, porcine stress syndrome, ryanodine receptor, SNPs, H-FABP

\section{INTRODUCTION}

During transport to the slaughter plant, nonambulatory pigs with no injuries cause severe economic loss for the swine industry. This has raised serious concerns about animal welfare and pre-slaughter management such as transportation, lairage condition, and marketing process in last decades (Gregory, 2008; Johnson et al., 2013). In Taiwan, market-weight pigs are sold alive in auction markets. It has been reported that the percentage of pigs rendered nonambulatory during transportation and auction process was about $1.15 \%$ and their mortality rate was $0.21-0.45 \%$ (Huang et al., 2011). Besides, environmental and management factors, the well known disease related to pre-slaughter loss is Porcine Stress Syndrome (PSS) which is associated with a point mutation of Cytosine (C) to Thymine (T) at nucleotide 1843 in the gene RYR1 (Fujii et al., 1991). RYR1 has a negative impact on pre-slaughter death and pork quality; however, homozygous and heterozygous pigs show higher lean yield and better feed efficiency (De Smet et al., 1996; Band et al., 2005; Leach et al., 1996; Murray and Johnson 1998). Besides RYR1, Heart Fatty Acid-Binding Protein gene (H-FABP) is considered to be important for carcass and meat quality, especially for intramuscular fat and eye muscle area (Gerbens et al., 1999; Kocwin et al., 2006; Lin et al., 2002; Zhang et al., 2001).

Genotyping of RYR1 and H-FABP for mutations has been successfully employed as a means of genetic selection in pig breeding program (Robinson and Buhr, 2005). Previously, genotyping was performed either by sequencing or Polymerase Chain Reaction-Restriction Fragment Length Polymorphism (PCR-RFLP) (O'Brien et al., 1993; Zeng et al., 2005). However, these methods are either expensive or time consuming. But a kind of Single Nucleotide Polymorphism (SNP) genotyping technique has been discussed in animal genetics (Garvin et al., 2010; Gupta et al., 2008;

Corresponding Author: Chean-Ping Wu, Department of Animal Science, National Chiayi University, 300 Syuefu Road, Chiayi, Taiwan 
Res. J. Anim. Sci., 11 (5-6): 12-17, 2017

\begin{tabular}{|c|c|c|c|}
\hline Gene name & PCR primer sequences $5^{\prime} \rightarrow 3^{\prime}$ & Product length $(b p)$ & Extension primer sequences $5^{\prime} \rightarrow 3^{\prime}$ \\
\hline RYR 1 & $\begin{array}{l}\text { Stress-gene F1: } \\
\text { GTTCCCTGTGTGTGTGCAAT } \\
\text { Stress-gene R1 } \\
\text { AGCAAGTTCTCAGTAATGAGAT }\end{array}$ & 67 & $\begin{array}{l}\text { CRC-1843: } \\
\text { GCAATGGTGTGGCCGTG (T/C) }\end{array}$ \\
\hline $\begin{array}{l}\text { H-FABP 5' } \\
\text { upstream }\end{array}$ & $\begin{array}{l}\text { H-FABP upst F2: } \\
\text { GGACCCAAGATGCCTACGCCG } \\
\text { H-FABP upst R2: } \\
\text { CTGCATCTTTGACCAAGAGG }\end{array}$ & 709 & $\begin{array}{l}\text { H-FABP upst-1324: } \\
\text { CAGCGGCTTCCTTCTCAGAT (C/T) }\end{array}$ \\
\hline $\mathrm{H}-\mathrm{FABP}$ intron 2 & $\begin{array}{l}\text { H-FABP intr F2: } \\
\text { ATTGCTTCGGTGTGTTTGAG } \\
\text { H-FABP intr R2: } \\
\text { TCAGGAATGGGAGTTATTGG }\end{array}$ & 816 & $\begin{array}{l}\text { H-FABP intr-1811: } \\
\text { AAACGCCAACAGTTCTATGGGATG (C/G) } \\
\text { H-FABP intr-1489: } \\
(\text { GACT) })^{2} \text { ACATCTACCCTCTCTCAGGA (C/T) }\end{array}$ \\
\hline
\end{tabular}

Ragoussis, 2009). This approach is included a single or multiple allelic-discrimination principles, following analyzed with signal detection mechanisms. SNP markers have been further used to breed high values of economic traits by breeders. Advantages of SNP genotyping techniques which was rapid, high throughput and accurate was developed for assessing genetic variation (Huang et al., 2015; Syvanen, 2001). The purpose of this study was to use this assay for determining nucleotide variations in RYR1 and H-FABP and to investigate the frequency of these genotypes in pigs exhibiting PSS during transportation and auction period.

\section{MATERIALS AND METHODS}

The protocol used in this study was approved by institutional animal care and use committee of national chiayi university.

Animals and DNA preparation: Six hundred and fifty five pigs that were exposed to stress due to transportation and auction and hence, prone to PSS were sampled from the main auction market in central Taiwan during summer season (June-August). These pigs were either Landrace $\mathrm{x}$ Yorkshire $\mathrm{x}$ Duroc or Landrace $\mathrm{x}$ Duroc hybrids. The lot contained three hundred and twenty seven female and three hundred and twenty eight male pigs. The transport time from farms to the auction market was approximately $1 \mathrm{~h}$ and pigs were auctioned after at least $3 \mathrm{~h}$ of lairage. No pigs were given sedatives or treated with electric prods during loading, unloading or the auction process. PSS and normal pigs were assessed among the pigs arriving in the lairage in the auction market (transportation group) or those being auctioned (auction group) and blood samples were collected by the veterinarian of the auction market. PSS pigs were defined as pigs with muscle and tail tremor, labored and irregular breathing, blanching and reddening of skin, a rapid rise in body temperature, the ones that collapsed and showed muscle rigidity. Blood samples were collected from the jugular vein of each animal and stored in tubes containing sterile-EDTA as the anticoagulant. Genomic DNA was isolated from the pig blood as described by Shian and Huang (1997) and quantified by spectrophotometry at S2000 UV/VIS (Tomy Seiko Co., LTD, Tokyo, Japan). The genomic DNA was then diluted with double distilled water to a concentration of $50 \mathrm{ng} / \mu \mathrm{L}$ and used for PCR.

SNaPshot method: DNA fragments from RYR1 and portions of the 5'-upstream region and intron 2 Section of $\mathrm{H}-\mathrm{FABP}$ were amplified in a single multiplex PCR. Each reaction was carried out in a total volume $10 \mu \mathrm{L}$ which contained $25 \mathrm{ng}$ genomic DNA as the template, $5 \mathrm{mM}$ $\mathrm{MgCl}_{2}, 2.5 \mathrm{mM}$ dNTPs, $50 \mathrm{pmol} / \mu \mathrm{L}$ each of the six primers (Table 1 and $0.2 \mathrm{U}$ of DyNAzyme II polymerase (Finnzymes Inc., Finland). Reactions were carried out in a PCR thermocycler (GeneAmp ${ }^{\circledR}$ 2700, Applied Biosystems), using the following conditions: an initial denaturation step at $94^{\circ} \mathrm{C}$ for $5 \mathrm{~min}$, followed by 35 cycles consisting of denaturation at $94^{\circ} \mathrm{C}$ for $30 \mathrm{sec}$, annealing at $60^{\circ} \mathrm{C}$ for $1 \mathrm{~min}$, and extension at $72^{\circ} \mathrm{C}$ for $1 \mathrm{~min}$ with a final extension at $72^{\circ} \mathrm{C}$ for $7 \mathrm{~min}$. Unincorporated dNTPs and excess primers were inactivated and degraded by the addition of $0.2 \mathrm{U}$ exonuclease I (Epicentre ${ }^{\circledR}$ ) and $0.5 \mathrm{U}$ shrimp alkaline phosphatase (SAP; Promega) in a final reaction volume of $2 \mu \mathrm{L}$ which contained $1.5 \mu \mathrm{L}$ of the PCR product. This degradation reaction mixture was incubated at $37^{\circ} \mathrm{C}$ for $2 \mathrm{~h}$ and the enzymes were subsequently, inactivated at $75^{\circ} \mathrm{C}$ for $15 \mathrm{~min}$.

These treated PCR products were then processed in a multiplex mini-sequencing reaction where four SNP loci were simultaneously analyzed. The SNP-specific primers designed to detect nucleotide variations by mini-sequencing at the selected SNP sites are listed in Table 1. Conditions were created so that, when the template DNA annealed next to each SNP site, extension by DNA polymerase added just a single complementary dideoxyribonucleoside Triphosphate (ddNTP) to the nucleotide at the polymorphic site (Table 1). Each of the four ddNTPs was labeled with a spectrally distinct 
fluorophore. In addition to the labeled ddNTPS, the primer length differed at the $5^{\prime}$ end of each SNP site and non-homologous d (GATC). Two fluorophores were used to analyze each SNP (Table 2). After the multiplex PCR, the nucleotide variation was verified by fluorescence and the length of PCR product using capillary electrophoresis.

Each multiplex mini-sequencing reaction contained $2 \mu \mathrm{L}$ treated multiplex PCR product, various concentrations of the minisequencing primers, $0.7 \mu \mathrm{L}$ $\mathrm{SNaPshot}^{\mathrm{TM}}$ multiplex ready reaction mix AmpliTaq ${ }^{\circledR}$ DNA polymerase, fluorescently labeled ddNTPs and reaction buffer (Applied Biosystems) in a total volume $4 \mu \mathrm{L}$. The reaction mixture was subjected to 25 single-base extension cycles comprising denaturation at $96^{\circ} \mathrm{C}$ for $10 \mathrm{sec}$, primer annealing at $50^{\circ} \mathrm{C}$ for $5 \mathrm{sec}$ and primer extension at $60^{\circ} \mathrm{C}$ for $10 \mathrm{sec}$. The unincorporated fluorescent ddNTPs were removed by adding $0.35 \mathrm{U}$ of shrimp alkaline phosphatase to the mix and incubating at $37^{\circ} \mathrm{C}$ for $1 \mathrm{~h}$, followed by heat inactivation at $75^{\circ} \mathrm{C}$ for $15 \mathrm{~min}$. Automated capillary electrophoresis was used to determine the nucleotide sequence at each SNP which was carried out using a mixture of $0.5 \mu \mathrm{L}$ of treated multiplex minisequencing products, $9.25 \mu \mathrm{L}$ of $\mathrm{HiDi}^{\mathrm{TM}}$ formamide and $0.25 \mu \mathrm{L}$ of GeneScan-120 LIZ size standard (Applied Biosystems). The products were resolved on an ABI PRISM ${ }^{\circledR} 3100$ Genetic Analyzer (Applied Biosystems) for $45 \mathrm{~min}$ and any nucleotide variation was detected by Gene $\operatorname{Scan}^{\mathrm{TM}}$ Version 3.7 Application Software (Applied Biosystems). Point mutations were verified by their fluorescent color and length (Table 2).

\section{RESULTS AND DISCUSSION}

The nucleotide variations of four SNPs in RYR and H-FABP were detected unambiguously and simultaneously by the primer extension method. The migration distance of the labeled multiplex PCR product after electrophoresis depended on the length of the designed primer and the molecular weight of the labeled fluorescent product. Moreover, homozygous or heterozygous genotypes were distinguished by the expression of peaks of one or two different colors, respectively, at each SNP site (Table 2 and Fig. 1). For example, the RYR1 product containing $1843 \mathrm{C} \rightarrow \mathrm{T}$ polymorphism migrated more slowly than the one containing C; thus, the SNP for the RYR1 $1843 \mathrm{C} / \mathrm{T}$ heterozygous sample displayed two peaks having a minimum overlap (Fig. 1b). The $\mathrm{C} / \mathrm{G}$ heterozygous genotype in the SNP 1811 of H-FABP showed two overlapping peaks that could be distinguished by the variations in the fluorescence of ddGTP (blue) and ddCTP
Table 2: Designed minisequencing sites and peaks color used to detect the RYR1 and H-FABP genotypes in PSS pigs

\begin{tabular}{lllll}
\hline Gene (SNP site) & Genotype & $\begin{array}{l}\text { Detection } \\
\text { base }\end{array}$ & $\begin{array}{l}\text { Detection } \\
\text { length, bp }\end{array}$ & $\begin{array}{l}\text { Peak } \\
\text { color }\end{array}$ \\
\hline RYR 1 (1843) & $\mathrm{NN}$ & $\mathrm{C}$ & 20 & Black \\
& $\mathrm{Nn}$ & $\mathrm{C} / \mathrm{T}$ & $20 / 23$ & $\begin{array}{l}\text { Black/Red } \\
\text { Red }\end{array}$ \\
& $\mathrm{nn}$ & $\mathrm{T}$ & 23 & \\
& & & & Red \\
H-FABP 5' & $\mathrm{HH}$ & $\mathrm{T}$ & 24 & Black/Red \\
upstream (1324) & $\mathrm{Hh}$ & $\mathrm{T} / \mathrm{C}$ & $23 / 24$ & Black \\
& $\mathrm{hh}$ & $\mathrm{C}$ & 23 & \\
& & & & Black \\
H-FABP intron 2 & $\mathrm{DD}$ & $\mathrm{C}$ & 26 & Black/Blue \\
(1811) & $\mathrm{Dd}$ & $\mathrm{C} / \mathrm{G}$ & 26 & Blue \\
& $\mathrm{dd}$ & $\mathrm{G}$ & 26 & Black \\
& & & & Black/Red \\
H-FABP intron 2 & $\mathrm{AA}$ & $\mathrm{C}$ & 29 & Red \\
(1489) & $\mathrm{Aa}$ & $\mathrm{C} / \mathrm{T}$ & $29 / 30$ & \\
& aa & $\mathrm{T}$ & 3 &
\end{tabular}

(black) (Table 2, Fig. 1a-c). We found that the genotype nn (a homozygote with T at 1843) of RYR1 was the most common allele in pigs that developed PSS during transport and auction period. The frequency of the $\mathrm{nn}$ genotype was higher in the transportation (0.6) and auction group $(0.71)$ than in the normal group $(0.01)$ (Table 3). Three SNP sites in H-FABP were also examined. The genotype frequency of each locus showed no difference in the normal, transport and auction groups. However, it is interesting to note that the major genotype was different among these loci. For the $\mathrm{H}$ allele (5'upstream region at position 1324), the $\mathrm{HH}$ genotype (T/T) was the major genotype with a frequency of 0.82 . For the $\mathrm{D}$ allele (intron 2 at position 1811), the frequency was 0.04 for the DD genotype $(\mathrm{C} / \mathrm{C}) 0.42$ for the Dd genotype $(\mathrm{C} / \mathrm{G})$ and 0.62 for the dd genotype $(\mathrm{G} / \mathrm{G})$. In contrast to the former two alleles mentioned above, the heterozygous genotype $(\mathrm{Aa}, \mathrm{C} / \mathrm{T}$ ) of the A allele (intron 2 at position 1489) was most commonly encountered with a frequency of 0.52 . The occurrence of the homozygous recessive genotype (aa, $\mathrm{T} / \mathrm{T}$ ) was rare $(0.02)$.

The transportation and auction processes present a combination of physical and unfamiliar experiences such as high ambient temperature, noise and pig-human interaction that can be stressful for pig. These sequential stressors can induce PSS which results in acute death and poor pork quality (Johnson et al., 2013; Warriss, 2004). Besides, its association with environmental factors, PSS is closely related to C to T polymorphism in RYR1 at nucleotide position 1843 (De Smet et al., 1996). In Taiwan, market-weight pigs are auctioned alive. After transportation and lairage, pigs are forced to walk on a narrow route (about $10 \mathrm{~m}$ length and $0.5 \mathrm{~m}$ width) one by one. As the pigs walk through the route, competitive bidding is held within 1 min. Body conformation and type are the most important criteria assessed by buyers who prefer pigs with a lean-meat 
Res. J. Anim. Sci., 11 (5-6): 12-17, 2017

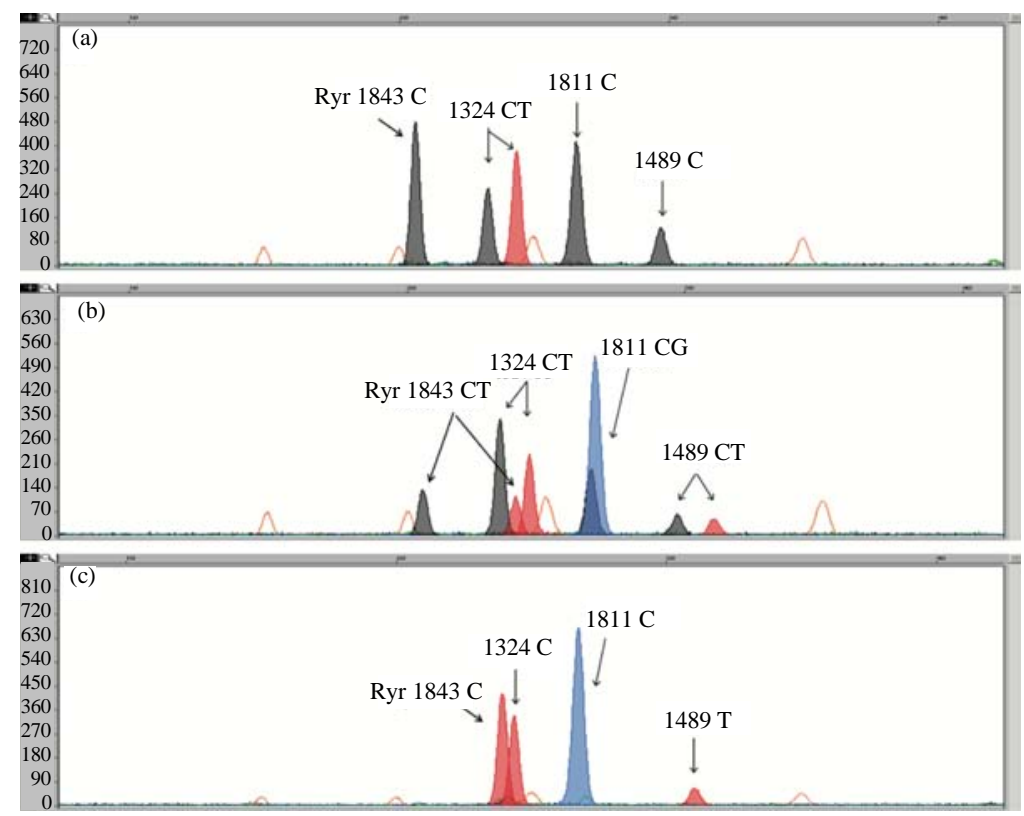

Fig. 1: Characterization of RYR1 and H-FABP genotypes in pigs using one minisequencing reaction; a) NNHhDDAA genotype; b) NnHhDdAa genotype; c) nnHHddaa genotype. Colors are assigned to individual ddNTPs as follows: black $=\mathrm{C}$, blue $=\mathrm{G}$, red $=\mathrm{T}$, the GeneScan ${ }^{\mathrm{TM}}-120 \mathrm{LIZ}^{\mathrm{TM}}$ size standards are shown in orange

Table 3: Distribution of RYR1 and H-FABP genotypes in pigs that developed serious PSS during normal, transportation and auction

\begin{tabular}{|c|c|c|c|c|c|c|c|c|c|c|c|c|}
\hline \multirow[b]{2}{*}{ Gene } & \multicolumn{3}{|c|}{ RYR1 } & \multicolumn{9}{|c|}{ H-FABP } \\
\hline & $\mathrm{NN}$ & $\mathrm{Nn}$ & $\mathrm{nn}$ & $\mathrm{HH}$ & Hh & Hh & DD & Dd & $\mathrm{dd}$ & $\mathrm{AA}$ & Aa & аa \\
\hline Genotype & $\mathrm{CC}$ & $\mathrm{CT}$ & TT & TT & CT & $\mathrm{CC}$ & $\mathrm{CC}$ & CG & GG & $\mathrm{CC}$ & $\mathrm{CT}$ & TT \\
\hline Normal $(\mathbb{N}) \sigma^{*}$ & 235 & 10 & 3 & 203 & 40 & 5.00 & 10 & 90 & 149 & 109 & 127 & 12 \\
\hline $\mathrm{n}=496 \stackrel{9}{\circ}$ & 233 & 13 & 2 & 206 & 38 & 4.00 & 8 & 93 & 146 & 114 & 121 & 13 \\
\hline Relative frequency & 0.94 & 0.05 & 0.01 & 0.82 & 0.16 & 0.02 & 0.04 & 0.37 & 0.59 & 0.45 & 0.50 & 0.05 \\
\hline Transportation $(\mathrm{T}) \sigma^{*}$ & 2 & 7 & 12 & 17 & 4 & 0.00 & 1 & 7 & 13 & 9 & 12 & 0 \\
\hline $\mathrm{n}=42+$ & 3 & 5 & 13 & 17 & 3 & 1.00 & 0 & 8 & 13 & 10 & 10 & 1 \\
\hline Relative frequency & 0.12 & 0.29 & 0.60 & 0.81 & 0.17 & 0.02 & 0.02 & 0.36 & 0.62 & 0.45 & 0.52 & 0.02 \\
\hline Auction (A) o $\sigma^{7}$ & 4 & 13 & 42 & 49 & 9 & 1.00 & 1 & 23 & 35 & 27 & 30 & 2 \\
\hline $\mathrm{n}=117$ क & 5 & 12 & 41 & 47 & 9 & 2.00 & 2 & 26 & 30 & 29 & 29 & 0 \\
\hline Relative frequency & 0.08 & 0.21 & 0.71 & 0.82 & 0.15 & 0.03 & 0.03 & 0.42 & 0.56 & 0.48 & 0.50 & 0.02 \\
\hline Total Average $(\mathrm{T}+\mathrm{A})$ & 0.10 & 0.25 & 0.66 & 0.82 & 0.16 & 0.03 & 0.03 & 0.39 & 0.59 & 0.47 & 0.51 & 0.02 \\
\hline
\end{tabular}

phenotype. Therefore, pig farmers or breeders tend to select herds with lean-meat phenotype and high meat production. This breeding program focused on lean-meat phenotype is coupled with better growth performance and high susceptibility to exertional myopathy (Altrock and Holleben, 1999); however, it might potentially result in an increase in then genotype and in the incidence of PSS and Pale, Soft, Exudative meat (PSE). Studies have shown that Nn pigs have better feed efficiency and carcass characteristics than NN pigs (Leach et al., 1996). Fisher et al. (2000) concluded that the inclusion of halothane gene had positive impacts on carcass characteristics such as carcass length and lean content of certain cuts but was associated with a higher incidence of PSE (Fisher et al.,
2000). In our study, pigs which developed PSS had a greater (0.9) incidence of the $\mathrm{n}$ RYR1 genotype. The result was similar to that reported by Murray and Johnson (1998) who showed that more than $50 \%$ of pre-slaughter deaths were mainly caused by the presence of halothane (n) gene in Western Canadian commercial packing plants. However, in our study, pigs that were identified to have PSS showed serious physical symptoms and were slaughtered before their death. It is interesting that PSS was present not only in the nn carrier pigs but also partially in the $\mathrm{NN}$ or $\mathrm{Nn}$ pigs. This result was similar to that by Ritter et al. (2008) who indicated that the pre-slaughter loss including nonambulatory and dead pigs was not only attributable to the nn genotype of RYR1 but also to the non-genetic 
factors. The H-FABP genotype which is another important gene for pig industry is a candidate gene for determining the muscle quality and might be associated with the degree of Intramuscular Fat (IMF) (Gerbens et al., 1997 ; 1998). The genotypes of H-FABP were observed to have significant effects on IMF at sites such as the eye muscle area (Gerbens et al., 1999; Lin et al., 2002; Zhang et al., 2001) but not on the backfat thickness (De Koning et al., 1999). A correlation between the genotype and variation in fat content was also found in the duroc breed (Gerbens et al., 1999). In this study, the frequencies of H-FABP genotype showed that there was a higher frequency of PSS development in the $\mathrm{HH}, \mathrm{dd}, \mathrm{Dd}, \mathrm{Aa}$ and AA genotypes whereas lower frequencies were associated with the $\mathrm{Hh}, \mathrm{hh}, \mathrm{DD}$ and aa genotypes. Our data also showed that the frequencies of the dominant genotypes were $0.98,0.42$ and 0.98 for $\mathrm{H}$ ( $\mathrm{HH}$ and $\mathrm{Hh}$ ) D (DD and Dd) and A (AA and Aa) alleles, respectively. These genotype frequencies were inconsistent with those reported in previous studies (Gerbens et al., 1999; Lin et al., 2002) using pure-breed pigs. However, the genotype frequency of H-FABP and its effect on IMF differed among the pig breeds and populations (Nechtelberger et al., 2001; Pang et al., 2006). In our study, samples were collected from hybrid pigs in which the variation in the genotype frequencies was more significant than in the pure-breed pigs. Therefore, a large population was needed to investigate the correlation between PSS and the genotype frequency of H-FABP.

The advantages of the primer extension method such as SnaPshot assay are accuracy and automation for high throughput genotyping and therefore, this method is efficient for a large survey project and is ideal for a central laboratory (Gwee et al., 2003; Pati et al., 2004; Syvanen, 2001). Moreover, microarray analysis of SNPs has been used in commercial pig breeding (Kaminiski et al., 2008). Therefore, a primer extension method for simultaneous screening of five important mutations on two genes was developed in this study.

\section{CONCLUSION}

In conclusion, PSS was correlated with the SNP genotypes of RYR1 in pigs during transportation and auction period but not with H-FABP. A controlled breeding program to eliminate the nn pigs would be effective in reducing the pre-slaughter loss; however, improvements in humane handling and minimization of the stressors would be also necessary in the auction market.

\section{ACKNOWLEDGEMENT}

The researchers are grateful the animal research farm, National Chiayi University, Chiayi, Taiwan for providing the apparatus, facilities and animal care required in this study.

\section{REFERENCES}

Altrock, A.V. and K.V. Holleben, 1999. Sudden deaths in taking blood samples from fattening swine herds-experiences from practice. Berl. Munchener Vet. Weekly, 112: 86-90.

Band, G.D.O., S.E.F. Guimaraes, P.S. Lopes, A.S. Schierholt and K.M. Silva et al., 2005. Relationship between the porcine stress syndrome gene and pork quality traits of $\mathrm{F} 2$ pigs resulting from divergent crosses. Genet. Mol. Biol., 28: 88-91.

De Koning, D.J., L.L. Janss, A.P. Rattink, P.A. van Oers and B.J. de Vries et al., 1999. Detection of quantitative trait loci for backfat thickness and intramuscular fat content in pigs (Sus scrofa). Genetics, 152: 1679-1690.

De Smet, S.M., H. Pauwels, S. De Bie, D.I. Demeyer, J. Callewier and W. Eeckhout, 1996. Effect of halothane genotype, breed, feed withdrawal and lairage on pork quality of Belgian slaughter pigs. J. Anim. Sci., 74: 1854-1863.

Fisher, P., F.D. Mellett and L.C. Hoffman, 2000. Halothane genotype and pork quality. 1. carcass and meat quality characteristics of three halothane genotypes. Meat Sci., 54: 97-105.

Fujii, J., K. Otsu, F. Zorzato, S. de Leon and V.K. Khanna et al., 1991. Identification of a mutation in porcine ryanodine receptor associated with malignant hyperthermia. Science, 253: 448-451.

Garvin, M.R., K. Saitoh and A.J. Gharrett, 2010. Application of single nucleotide polymorphisms to non-model species: A technical review. Mol. Ecol. Resour., 10: 915-934.

Gerbens, F., A.J. van Erp, F.L. Harders, F.J. Verburg, T.H. Meuwissen, J.H. Veerkamp and M.F. te Pas, 1999. Effect of genetic variants of the heart fatty acid-binding protein gene on intramuscular fat and performance traits in pigs. J. Anim. Sci., 77: 846-852.

Gerbens, F., A.J.M.V. Erp, J.H. Veerkamp and M.F.W.T. Pas, 1998. Heart fatty-acid binding protein gene variants are associated with intramuscular fat content and back fat thickness in pigs. Proceedings of the 6th World Congress on Genetics Applied to Livestock Production 1998, January 11-16, 1998, Wageningen University and Research Centr, Armidale, Australia, pp: $187-190$. 
Gerbens, F., G. Rettenberger, J.A. Lenstra, J.H. Veerkamp and M.F.T. Pas, 1997. Characterization, chromosomal localization and genetic variation of the porcine heart fatty acid-binding protein gene. Mamm. Genome, 8: 328-332.

Gregory, N.G., 2008. Animal welfare at markets and during transport and slaughter. Meat Sci., 80: 2-11.

Gupta, P.K., S. Rustgi and R.R. Mir, 2008. Array-based high-throughput DNA markers for crop improvement. Heredity, 101: 5-18.

Gwee, P.C., K. Tang, J.M. Chua, E.J. Lee and S.S. Chong et al., 2003. Simultaneous genotyping of seven single-nucleotide polymorphisms in the MDR1 gene by single-tube multiplex minisequencing. Clin. Chem., 49: 672-676.

Huang, C.W., Y.T. Lin, S.T. Ding, L.L. Lo and P.H. Wang et al., 2015. Efficient SNP discovery by combining microarray and lab-on-a-chip data for animal breeding and selection. Microarrays, 4: 570-595.

Huang, Y.H., C.K. Chou, C.C. Ju and S.W. Roan, 2011. Production and marketing management information system of pig farms. J. Agric. Assoc. China, 12: 270-286.

Johnson, A.K., L.M. Gesing, M. Ellis, J.J. McGlone and E. Berg et al., 2013. 2011 and 2012 early careers achievement awards: Farm and pig factors affecting welfare during the marketing process. J. Sci., 91: 2481-2491.

Kaminiski, S., P. Brym, A. Rusc and E. Wojcik, 2008. Microarray of SNPs for diverse applications in commercial pig breeding. Pol. J. Vet. Sci., 12: 69-74.

Kocwin, P.M., E. Krzecio and W. Przybylski, 2006. Pork quality and methods of its evaluation-a review. Pol. J. Food Nutr. Sci., 3: 241-248.

Leach, L.M., M. Ellis, D.S. Sutton, F.K. McKeith and E.R. Wilson, 1996. The growth performance, carcass characteristics and meat quality of halothane carrier and negative pigs. J. Anim. Sci., 74: 934-943.

Lin, W.H., L.S. Huang, J. Ren, S.H. Deng and W.J. Wang et al., 2002. Research on genetic variation of heart fatty acid-binding protein gene in ten pig breeds. Yi chuan xue bao = Acta Genetica Sin., 29: 12-15.

Murray, A.C. and C.P. Johnson, 1998. Impact of the halothane gene on muscle quality and pre-slaughter deaths in Western Canadian pigs. Can. J. Anim. Sci., 78: 543-548.
Nechtelberger, D., V. Pires, J. Soolknet, G. Brem and M. Mueller et al., 2001. Intramuscular fat content and genetic variants at fatty acid-binding protein loci in Austrian pigs. J. Anim. Sci., 79: 2798-2804.

O'Brien, P.J., H. Shen, C.R. Cory and X. Zhang, 1993. Use of a DNA-based test for the mutation associated with porcine stress syndrome (malignant hyperthermia) in 10,000 breeding swine. J. Am. Vet. Med. Assoc., 203: 842-851.

Pang, W.J., L. Bai and G.S. Yan, 2006. Relationship among H-FABP gene polymorphism, intramuscular fat content and adipocyte lipid droplet content in main pig breeds with different genotypes in Western China. Acta Genet. Sin., 33: 515-524.

Pati, N., V. Schowinsky, O. Kokanovic, V. Magnuson and S. Ghosh, 2004. A comparison between SNaPshot, pyrosequencing and biplex invader SNP genotyping methods: Accuracy, cost and throughput. J. biochem. Biophys. Methods, 60: 1-12.

Ragoussis, J., 2009. Genotyping technologies for genetic research. Ann. Rev. Genomics Hum. Genet., 10: 117-133.

Ritter, M.J., M. Ellis, G.R. Hollis, F.K. McKeith and D.G. Orellana et al., 2008. Frequency of the HAL-1843 mutation of the ryanodine receptor gene in dead and nonambulatory-noninjured pigs on arrival at the packing plant. J. Anim. Sci., 86: 511-514.

Robinson, J.A.B. and M.M. Buhr, 2005. Impact of genetic selection on management of boar replacement. Theriogenology, 63: 668-668.

Shian, J.W. and M.C. Huang, 1997. The probe of repeatitive sequence for DNA fingerprinting in holstein cattle. J. Agric. Assoc. China, 177: 1-10.

Syvanen, A.C., 2001. Accessing genetic variation: Genotyping single nucleotide polymorphisms. Nat. Rev. Genet., 2: 930-942.

Warriss, P.D., 2004. The transport of animals: A long way to go. Vet. J., 168: 213-214.

Zeng, Y.Q., G.L. Wang, C.F. Wang, S.D. Wei and $\mathrm{Y}$. Wu et al., 2005. Genetic variation of $\mathrm{H}-\mathrm{FABP}$ gene and association with intramuscular fat content in Laiwu Black and four western pig breeds. Asian Aust. J. Anim. Sci., 18: 13-16.

Zhang, G., H. Cao, L. Wang, H. Li and Y. Zheng, 2001. Genetic variation in 5'-upstream region and the second intron of H-FABP gene in nine pig breeds. Acta Vet. Zootechnica Sin., 33: 340-343. 